\title{
Dynamic Indicators Influencing Design Solution for Modernization of the Freight Rolling Stock
}

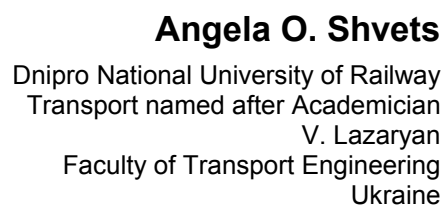

Angela O. Shvets

cademician

\section{INTRODUCTION}

Wagon facilities are one of the most important and most complicated branches of railway transport, the basis of which is rolling stock. The successful implementation of the transportation process largely depends on the number of freight wagons and their operation efficiency. Therefore, the wagon structural design efficiency assumes importance. The carrying capacity of railways, the traffic handling cost, the possibility of mecha-nization and automation in wagons manufacture and repair, as well as in the process of making up trains and loading and unloading operations, depend on structural design efficiency $[1,2]$.

The modern freight wagon fleet is presented by a variety of types and designs. This is dictated by the need to ensure: the safety of the perishable freight, the prevention of damage to fragile freight, the protection of a certain freight classification from adverse weather conditions, movement at high speeds and minimizing the cost of wagon building, repairing and operating. At the same time, freight rolling stock should ensure the safety of train traffic $[3,4]$.

The mass character of the wagon fleet is its integral and essential feature. Even the smallest structural changes take on a large scale for the entire rolling stock fleet. When designing rolling stock, designers must determine whether the designed model will have the necessary dynamic characteristics. The answer can only be obtained intuitively by comparing the basic design parameters with a similar design already available or after its manufacture and dynamic running tests conducting. However, this process is long, so, a

Received: April 2021, Accepted: June 2021

Correspondence to: Angela O. Shvets

Faculty of Transport Engineering,

Lazaryana St., 2, Dnipro, Ukraine, 49010

E-mail: angela_Shvets@ua.fm

doi:10.5937/fme2103673S

(C) Faculty of Mechanical Engineering, Belgrade. All rights reserved preliminary assessment of the wagon dynamic characteristics at the design stage is of practical interest, which can be done using mathematical simulation $[5,6]$.

\section{ANALYSIS OF LATEST RESEARCH AND THE PROBLEM STATEMENT}

\subsection{Reducing the dead weight of rolling stock}

Reducing the dead weight of rolling stock is one of the main and very complex problems of transportation science and engineering. When solving it, it is necessary to take into account the whole variety of conditions that characterize the wagon building and operating. The possibilities for constructive improvement of wagons with the aim of facilitating them are very significant. Reducing the weight of rolling stock is especially important for wagon building, which is one of the main metal consumers. Wagons require fixed costs associated with their movement in operation, therefore, in wagon building a decrease in metal consumption leads not only to a decrease in the construction cost of products, but to an even more significant effect that is a decrease in operating costs of the railway industry. However, when solving these problems, designers have to take into account the whole variety of requirements for wagons and to consider various options for constructive solutions [7]

A decrease in freight wagon dead weight is usually accompanied by an increase in their capacity, as a result of which the carrying capacity of railways increases due to an increase in the train tonnage. With a constant size of traffic, it is possible to reduce the fleet of wagons and locomotives, the need to develop the rail tonnage capacity, as well as locomotive and train crews. If the wagon dead weight is reduced without increasing their capacity, then axial loads are reduced, as a result of which the service life of rails, wheels and brake pads is increased, and the operation of the axle boxes is 
facilitated. Reducing the loads on the wheel sets, and especially from the unsprung wagon parts, reduces the dynamic forces, which in turn allows reducing the wagon dead weight. Because the decrease in the wagon tonnage is accompanied by a decrease in their resistance to movement, it becomes possible to increase the rail tonnage capacity by increasing the train speed with a given locomotive power [8-10].

Consequently, reducing the wagon dead weight ensures an increase in the rail tonnage capacity, saving metal, reducing fuel and power consumption, speeding up transportation, reducing investment in wagon and locomotive fleets, developing the rail capacity and reducing the cost of rail transportation. Because wagons are mass products, even a slight decrease in their dead weight leads to a significant economic effect. At the same time, a decrease in the wagon dead weight should not cause a problem in the rail traffic safety, the operating reliability of the wagons, and other indicators characterizing the expediency of the design. It is also necessary to improve methods for calculating and testing the wagon and their individual parts strength.

\subsection{Strength of rolling stock elements}

To reduce the forces transmitted to the wagon parts when moving along the curve, and the forces caused by changes in speed and body oscillations, it is necessary to reduce the center of mass of the wagon and reduce its displacement from the vertical symmetry axis. A decrease in the center of mass is also advisable for freight wagons with a relatively short bogie center distance [11-14]. In trains the longitudinal forces sometimes reach a value exceeding the strength of the frame of some wagon designs. Studies have shown that the large values of impact and tractive forces are due mainly to the sudden starting of the train; the in draught of a partially compressed train, especially with a fully uncompressed tail end having wagons with brakes not released; and braking by a stop-crane in the train tail end at a low speed and a compressed train at the beginning of braking [15-18].

The magnitude of the forces transmitted by the draw-buffing gear to the frame and other wagon parts depends on the efficiency and rigidity of the automatic coupling absorbing devices, as well as on the incompatibility of the automatic coupling axes of the neighboring wagons. If the impact energy does not exceed the efficiency of the shock absorbing device, it is perceived elastically. If the impact energy exceeds the efficiency of the shock absorbing device, it will be completely compressed and the excess of energy will be perceived without dampening by the wagon structure (frame and other parts). Since the wagon structure rigidity significantly exceeds the rigidity of the absorbing devices, the impact forces increase sharply in this case [18, 19].

It is known that increasing train mass is one of the most effective ways to increase rail traffic. Therefore, sufficient strength of automatic couplers is required, corresponding to the large longitudinal forces that develop in trains of large mass [19-21]. In work [22], the body of the automatic coupler was calculated for the strength under the action of both tensile and compressive quasi-static and shock loads (Fig. 1, 2). The design scheme assumes the application of longitudinal forces to the stops at both ends of the wagon with a difference in the heights of the automatic couplers of the interacting wagons of $0.1 \mathrm{~m}$.

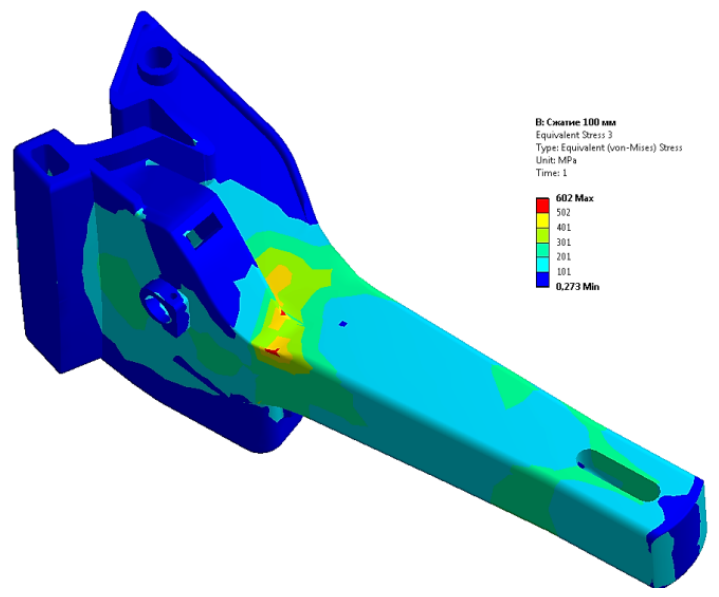

Figure 1. Equivalent stress distribution field, compression, displacement of the axis of an adjacent automatic coupling $0.1 \mathrm{~m}$ below the considered, $\mathrm{MPa}$

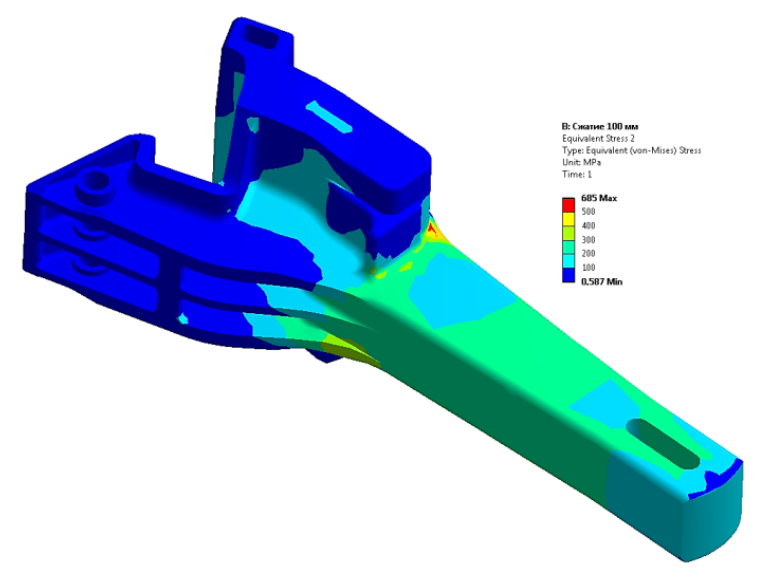

Figure 2. Equivalent stress distribution field, compression, displacement of the axis of an adjacent automatic coupling $0.1 \mathrm{~m}$ higher than the considered, MPa

When carrying out the calculations, the difference in the axes of the automatic couplers of adjacent wagons was taken into account only in the vertical plane. However, the radius of curvature of the coupling shank is $130 \mathrm{~mm}$, and the base plate, to which the longitudinal force of the train is transmitted by the coupling shank, has a radius of $150 \mathrm{~mm}$. As can be seen in (Fig. 1), the compressive force is transmitted by the automatic coupler to the base plate at a point, and in the case of skewing of the wagon $\mathrm{s}$ in the train, this point of contact can move across the wagon.

Under the action of tensile longitudinal forces (Fig. 2 ), the nature of the interaction changes significantly. For a more accurate determination of the dynamic loading and stability of the rolling stock, when determining the components of the longitudinal forces, it is necessary to take into account the action of neighboring wagons on each other $[20,21]$.

The presence of eccentricities also causes additional stresses in the nodes, in some cases exceeding the main stresses in the structure (Fig. 5). 


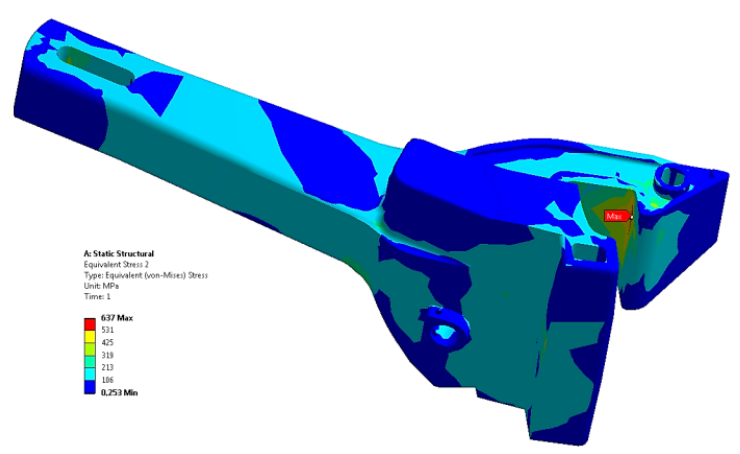

Figure 3. Equivalent stress distribution field, stretching, displacement of the axis of an adjacent automatic coupling $0.1 \mathrm{~m}$ below the considered, $\mathrm{MPa}$

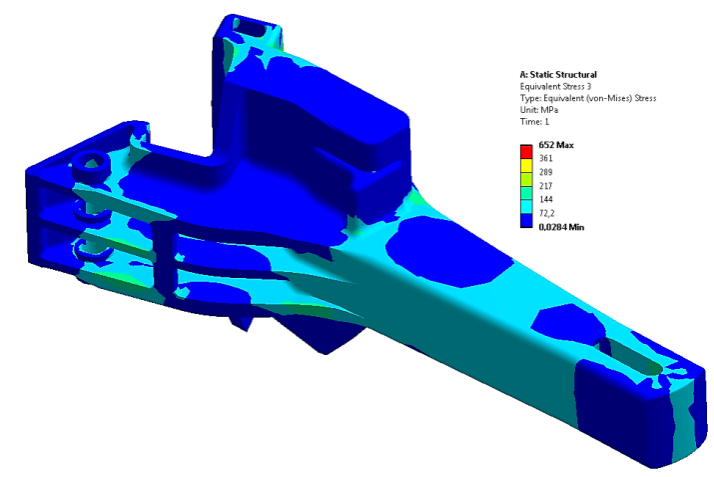

Figure 4. Equivalent stress distribution field, stretching, displacement of the axis of an adjacent automatic coupling $0.1 \mathrm{~m}$ higher than the considered, $\mathrm{MPa}$

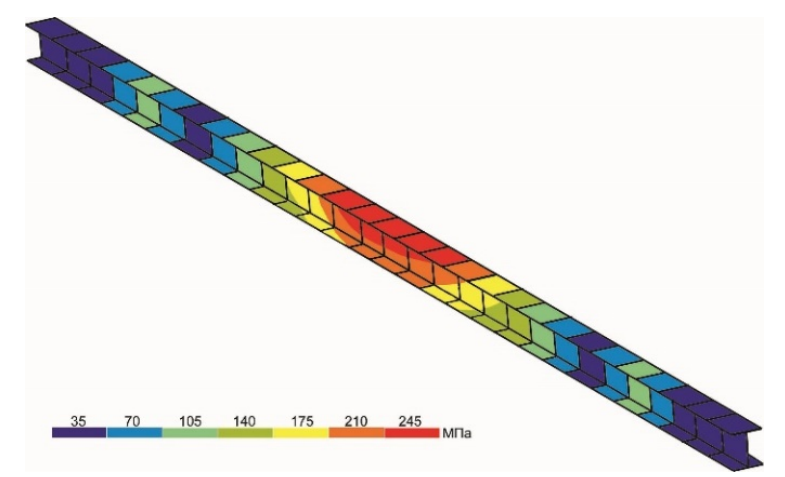

Figure 5. Diagram of the stress-strain state of the centre sill

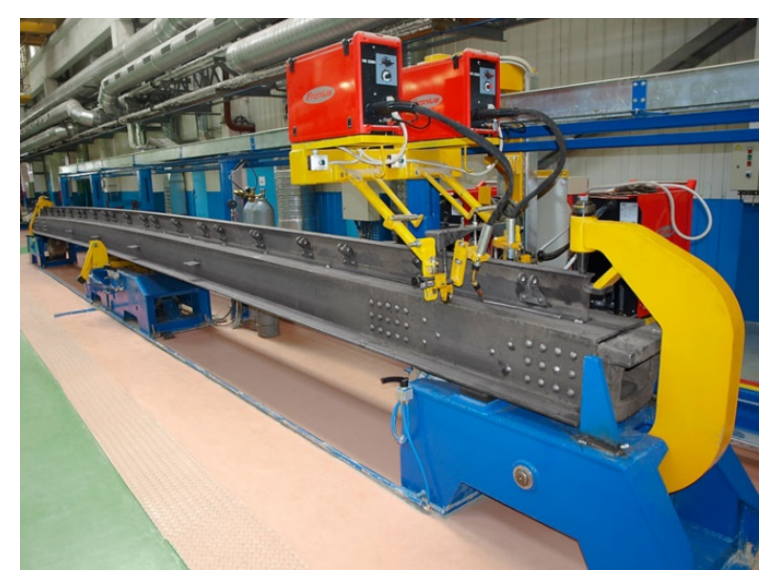

Figure 6. Robotic complex for manufacturing of the centre sill

Reducing eccentricities reduces additional stresses, which makes it possible to lighten the structure with a constant external load or to increase the external load without increasing the structure weight. The magnitude of the longitudinal forces is very significantly affected by the dimensions of the gaps in the wagon automatic couplings, so it is advisable to reduce them. The correct location of the automatic coupling on the wagon frame is of great importance (prevention of skewing the shock absorbing device and ensuring central loading of the centre sill). For this purpose, technological equipment is widely used (Fig. 6), which ensures the assembly of the elements of the centre sills and their further welding to each other in an automatic mode using an electromechanical system for tracking changes in the position of the axis of the welded joint [23].

\subsection{Square section of rolling stock elements}

The correct choice of the element shape is also important for lightening the structure. The form and size of the element section should be selected based on the conditions of the best resistance to basic deformation (ensuring the necessary strength and stability) with a minimum cross-sectional area (Fig. 7) (weight of the element). At the same time, the conditions of building (manufacturability) and operation (corrosion hazard, serviceability, etc.) of the structure must be taken into account (Fig. 8) [24].

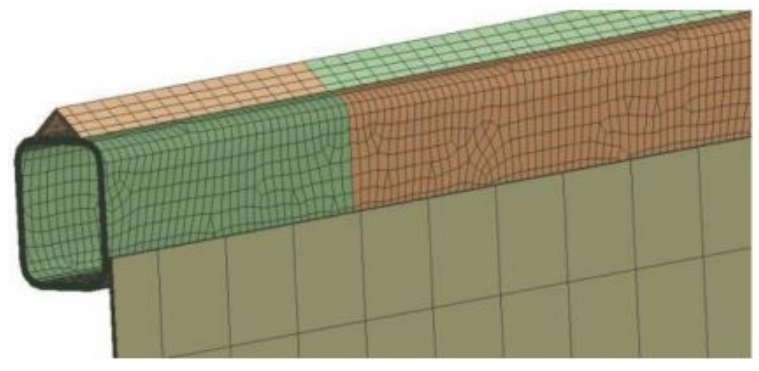

Figure 7. Fragment of a finite element model of a modernized gondola car

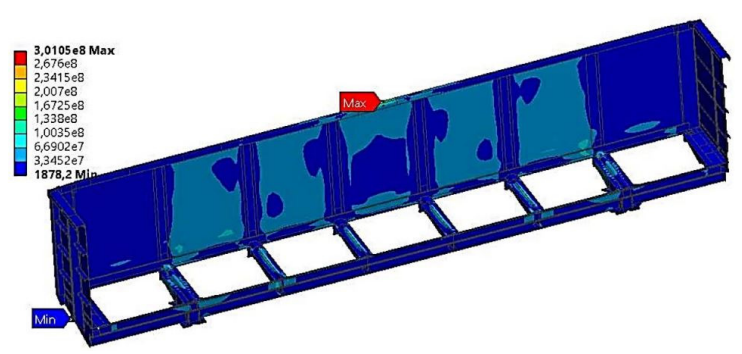

Figure 8. Stresses in the body of the modernized gondola car

Bending deformations in the vertical and horizontal planes and torsion are the main deformations for many wagons structural elements. Some of these elements are in the form of an I-beam or channel, which is not rational, since use of I-beam and channel sections is advantageous only when bending in the plane of their maximum rigidity; in another plane, they have a small moment of resistance, and also poorly resist torsional deformations. Meanwhile, deformations of constrained torsion can reach high values for some wagon parts. Therefore, it is more expedient to choose a box section having high rigidity in torsion and bending and a high resistance moment about both axes of inertia, for 
elements that perceive significant torsional and bending moments (in the vertical and horizontal planes). In wagon building, new effective rolled sections, differing from standard sections in more favorable characteristics of strength and stiffness should be widely used [25].

Modern rolling stock building is characterized by a transition from structures with supporting frames to solid bodies, i.e., to such structures in which the main loads acting on the wagon are perceived not only by the frame, but also by the floor, walls, and roof. Wagons with solid bodies are distinguished by a more rational use of walls, roof and floor metal and therefore they can be significantly lightened. In some wagon designs with a solid body of short length, it is advisable to leave the centre sill, but to lighten it significantly.

\subsection{Purpose and tasks of research}

So, the improvement of the wagon fleet through the creation of innovative designs or the modernization of individual components is a priority for improving the freight wagon technical and economic parameters. At the same time, the improvement of rolling stock provides for improved technical characteristics that will ensure that the main requirements (reliability and economic efficiency) are met. Evaluation of the dynamic characteristics and impact of the designed structure on the track is carried out after its building and dynamic driving test operation. The results of the dynamic interaction of rolling stock various types are usually not analyzed in terms of comparing the main design parameters and the minimal impact on the track structure.

The aim of the paper is a theoretical study of the influence of rolling stock various types on their main dynamic indicators and indicators of the interaction with the track structure, taking into account the loading mode and motion speed.

\section{MATERIALS AND METHODS OF RESEARCH}

It was noted in the works $[8,14,26]$ that during the movement of wagon in a train along the curved track sections, the forces of interaction between the wheels and rails are directly affected by the transverse forces that arise from the action of longitudinal forces in the auto-couplings of wagons in traction modes on long grades and during braking, especially the regenerative one. Moving along the curve, a wagon under the action of longitudinal forces in auto-couplings may take different positions relative to the track axis, which greatly affects the values of lateral horizontal forces of interaction and the force of friction of wheels and the rails. In the mode of braking, the compressive forces can contribute to the herringbone positioning of wagon $\mathrm{s}$ in the track, which leads to an increase in the angles of wheel climbing on the rails [20,21].

The complement of the mathematical models of spatial oscillations by the initial data with the specified inertial characteristics of the wagon and cargo elements makes it possible to approximate the results of calculations to the real state of objects and thereby increase the objectivity of mathematical and computer simulation. In the formation of the initial data necessary for the study of the dynamic properties of freight wagons, an important place is occupied by mass, geometric and inertial characteristics. These values are directly involved in determining the dynamic performance of the investigated railway vehicles [27, 28]. It was for solving this problem that the "Software complex for determining the moments of inertia of wagons bodies" was created [28].

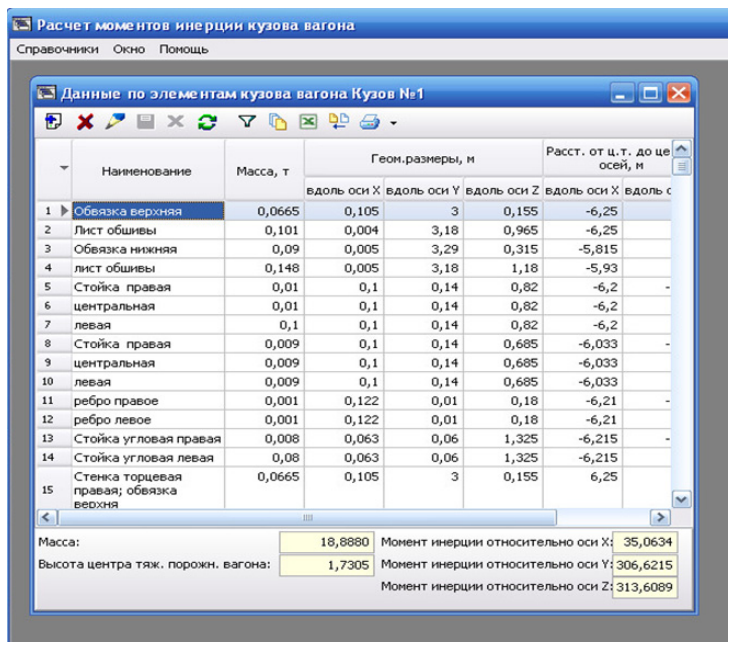

Figure 9. The wagons parameters panel "Software complex for determining the moments of inertia of wagons bodies"

A mathematical model describing the spatial oscillations of a wagon coupling as part of a train was proposed in [29, 30]. A mathematical model of spatial oscillations of a freight wagon in the form of a multimass nonlinear mechanical system with 58 degrees of freedom (body, two truck bolsters, four side frames, four wheel sets) [29].

Based on the mathematical model of the coupling movement, a package of applied programs has been developed. The system of differential equations has dynamic connections between coordinates and is reduced to the Cauchy normal form. A combined method is used to integrate the motion equations of freight wagon coupling in a train. The beginning of the solution (acceleration) was carried out using the Runge-Kutta method, and the continuation using the iterative Adams-Bashforth method.

The influence of the loading mode on the main dynamic indicators and the indicators of the freight rolling stock and rails interaction in curved tracks is studied in this paper. The stationary mode of motion with typical bogies 18-100 was studied in order to establish the influence of loading modes on the freight rolling stock dynamic loading. The wagon running gears, wheel thread and railhead profile were provided in the normal technical condition.

The studied wagon weight, the inertia moments of the body $I_{x}, I_{y}, I_{z}$ and the height body center of mass $h_{\mathrm{cm}}$ above the rail level change under various loading conditions. Preparatory calculations are given in table 1 .

Models of freight wagons presented in the Table 1 cover far from all types and sizes of bodies operated on the railway. The selection of the rolling stock given models is aimed at determining the optimal parameters of the bodies from the point of view of minimal dynamic interaction with the track, and not at comparing the specialized rolling stock types with each other. 
Table 1. Inertial and geometric characteristics of wagons with different loading modes

\begin{tabular}{|l|l|l|l|l|}
\hline \multirow{2}{*}{ Characteristics } & \multirow{2}{*}{\begin{tabular}{l} 
Symbol \\
\cline { 3 - 5 }
\end{tabular}} & & \multicolumn{3}{c|}{ Types of rolling stock } \\
\cline { 3 - 5 } & & \multicolumn{1}{c|}{$\begin{array}{c}\text { Open wagon } \\
12-532\end{array}$} & $\begin{array}{c}\text { Hopper wagon } \\
12-4034\end{array}$ & $\begin{array}{c}\text { Flat wagon } \\
13-401\end{array}$ \\
\hline Distance between bogie center & $2 L, \mathrm{~m}$ & 8.66 & 7.84 & 9.72 \\
\hline Weight of wagons & $M_{0}, \mathrm{t}$ & $76.5(13.3)^{*}$ & $88.34(18.72)$ & $63.6(13.6)$ \\
\hline \multirow{3}{*}{ Moments of inertia } & $I_{\mathrm{x}}, \mathrm{t} \cdot \mathrm{m}^{2}$ & $75(20)$ & $160(33.6)$ & $22(13.5)$ \\
\cline { 3 - 5 } & $I_{\mathrm{y}}, \mathrm{t} \cdot \mathrm{m}^{2}$ & $1050(300)$ & $1190(300)$ & $1194(240)$ \\
\cline { 3 - 5 } & $I_{\mathrm{z}}, \mathrm{t} \cdot \mathrm{m}^{2}$ & $1100(300)$ & $1245(307)$ & $1223(260)$ \\
\hline The height body center of mass above the rail level & $h_{\mathrm{cm}}, \mathrm{m}$ & $1.84(1.6)$ & $2.7(1.77)$ & $2.1(1.1)$ \\
\hline
\end{tabular}

* - the values of the wagon parameters in an empty mode are indicated in brackets

Table 2. Grade levels and permissible values of the dynamic indicators

\begin{tabular}{|c|c|c|c|}
\hline \multirow{2}{*}{ Indicator } & \multirow{2}{*}{ Grade level } & \multicolumn{2}{|c|}{ Permissible values } \\
\hline & & empty & loaded \\
\hline \multirow{4}{*}{$\begin{array}{l}\text { Maximum coefficient of dynamic addition of sprung parts } \\
\text { (vertical dynamics coefficient central stage of the bogie } \\
\text { suspension) } K_{\mathrm{dv}}\end{array}$} & excellent & 0.5 & 0.2 \\
\hline & good & 0.6 & 0.35 \\
\hline & satisfactory & 0.7 & 0.4 \\
\hline & permissible & 0.75 & 0.65 \\
\hline \multirow{4}{*}{$\begin{array}{l}\text { Maximum ratio of frame force to static axle loading } \\
\text { (coefficient of horizontal dynamics) } K_{\mathrm{dh}}\end{array}$} & excellent & 0.25 & 0.2 \\
\hline & good & 0.3 & 0.25 \\
\hline & satisfactory & 0.38 & 0.3 \\
\hline & permissible & 0.4 & 0.38 \\
\hline Safety factor of the wheel against derailment $K_{\mathrm{ds}}$ & permissible & \multicolumn{2}{|l|}{1.3} \\
\hline
\end{tabular}

The characteristics of rolling stock is usually assessed according to its technical indicators, among which the most important are the reliability and durability of the wagon, movement smoothness and stability against derailment, the influence on the track, and the absolute and relative movements of its units. When performing calculations of the dynamic characteristics of the designed rail vehicles, the calculated values of the main dynamic indicators are compared with the standardized values. The standardized values include the coefficient of vertical dynamics, the coefficient of horizontal dynamics, and the derailment stability coefficient. These indicators are assessed for various loading options. If all the standardized dynamic indicators of the wagon do not exceed the permissible values, and the stability indicators have a sufficient coefficient, then this indicates the good characteristics of the wagon's movement. Dynamic running teats shall confirm the calculations performed.

The grade levels and permissible values of the dynamic indicators of freight rolling stock in accordance with the regulatory documentation are given in table 2 .

\section{RESULTS}

The calculation results of the studied indicators are shown in Fig. 10-20. It is seen from Fig. 10 (a, b), in general, the vertical dynamics coefficients central stage of the bogie suspension increases with increasing motion speed. So, in the entire range of studied speeds, the coefficients $K_{\mathrm{dv}}$ do not exceed the permissible standard value both in the $R=600 \mathrm{~m}$ and in the $R=350 \mathrm{~m}$ curve in both loading modes.

The level of mark for $K_{\mathrm{dv}}$ is "excellent" in both curves (Table 2). Only an empty open wagon in the $R=350 \mathrm{~m}$ curve at a speed of $60 \mathrm{~km} / \mathrm{h}$ (Fig. 10, a) has more stable vertical dynamics. In the $R=350 \mathrm{~m}$ curve all three types of rolling stock have almost the same coefficients $K_{\mathrm{dv}}$ in the loaded mode, but in the $R=600 \mathrm{~m}$ curve, the open wagon and the flat wagon have the best vertical dynamics indicators in the speed range 50-70 $\mathrm{km} / \mathrm{h}$ in the empty mode (Fig. 10, b), and also excluding for the speed of $70 \mathrm{~km} / \mathrm{h}$ in the loaded mode. These wagon types have a lower mass and a lower center of mass than a hopper wagon.

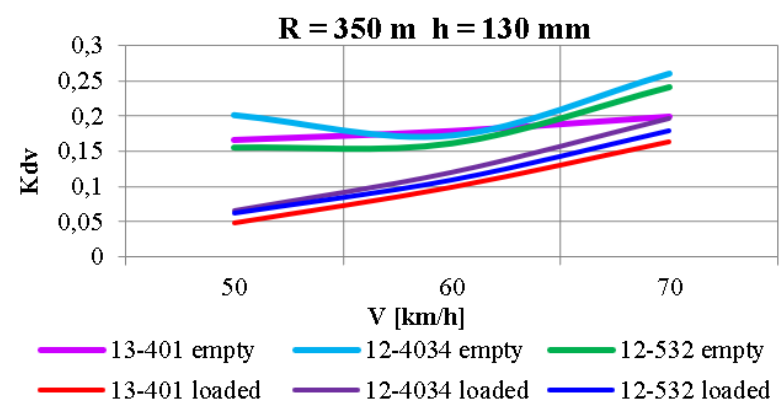

(a)

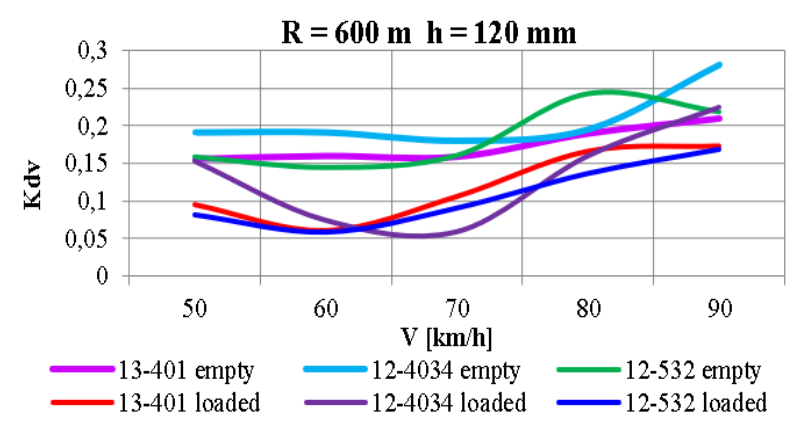

(b)

Figure 10. Variation vertical dynamics coefficient central stage of the bogie suspension with the motion speed: (a) $R=350$ m curve; (b) $R=600 \mathrm{~m}$ curve

Fig. $11(\mathrm{a}, \mathrm{b})$ shows the coefficient of horizontal dynamics $K_{\mathrm{dh}}$ diagrams. It can be seen, that the coeffi- 
cients of horizontal dynamics $K_{\mathrm{dh}}$ increase with an increase in the motion speed and a change in the loading mode and remain at the mark "excellent" in both $R=600$ $\mathrm{m}$ and $R=350 \mathrm{~m}$ curves. A loaded hopper wagon has the best coefficients of horizontal dynamics in both curves.

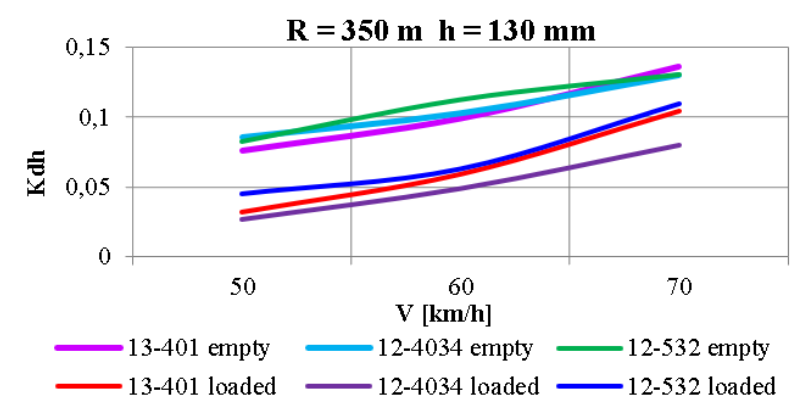

(a)

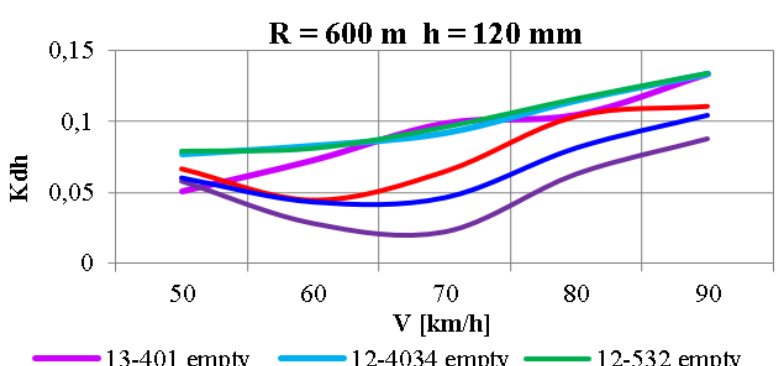

$12-4034$ empty $-12-532$ empty
$-13-401$ loaded
$-12-4034$ loaded

(b)

Figure 11. Variation of the coefficient of horizontal dynamics with the motion speed: (a) $R=350 \mathrm{~m}$ curve; (b) $\mathrm{R}=600 \mathrm{~m}$ curve

From the obtained results, it can be concluded that smaller weight and center of mass of the wagon improve the coefficients of vertical dynamics in the case of an increase in the motion speed; however, the coefficients of horizontal dynamics are better for heavy wagons with a high center of mass.

In addition, the calculation results obtained in Fig. 10 (a) and Fig. 11 (a) demonstrate that the parameters of the studied wagon models do not significantly affect the coefficients of the vertical dynamics of the central suspension stage and horizontal dynamics on curves of a small radius.

The safety factors of the wheel against derailment $K_{\mathrm{ds}}$ depend on the loading mode in the $R=350 \mathrm{~m}$ curve (Fig. 12, a) not as much as in the $R=600 \mathrm{~m}$ curve (Fig. $12, \mathrm{~b})$, and in both cases they exceed the minimum allowable value determined by the regulatory documentation. It follows from the results that in the case of an increase in the motion speed, the hopper wagon has high coefficients $K_{\mathrm{ds}}$, that can be explained by the increased wagon mass. In the $R=350 \mathrm{~m}$ curve, the safety factor of the wheel against derailment for the hopper wagon model 12-4034 has the highest value at the speed of 50 $\mathrm{km} / \mathrm{h}$. The flat wagon has the lowest coefficients $K_{\mathrm{ds}}$, due to the long wheelbase, which worsens guiding in the curves.

The appearance of minimums and maximums in Fig. 12 (b) can be explained as follows. The presence of a clearance between flange and rail leads to two opposite tendencies. On the one hand, in the presence of a clearance between flange and rail, the lateral displa- cement of the front wheelset towards the outer rail increases, as a result of which the difference in the radii of the circles along which the outer and inner wheels roll on the rails increases, which leads to a decrease in the longitudinal sliding of the wheels and the angle of runaway (wobbling) wheelset and helps to increase driving stability. On the other hand, the clearance provides greater freedom for tilting the bogie in the rail track, which can contribute to an increase in the angle of attack of the front wheelset and, accordingly, to a decrease in stability. The presence of these opposite tendencies leads to the appearance of extrema on the dependence curve $K_{\mathrm{ds}}$.

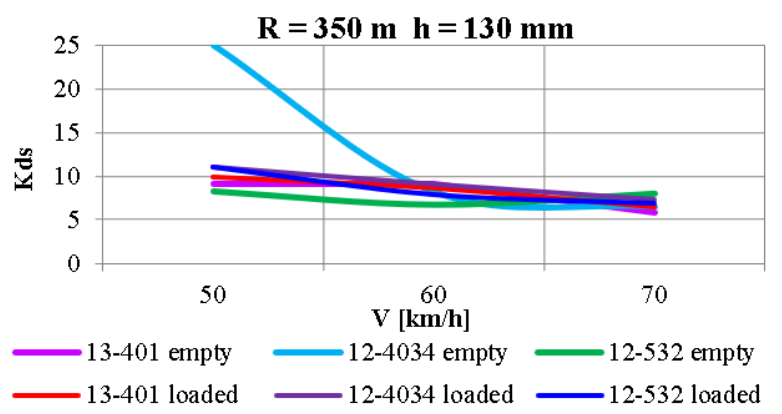

(a)

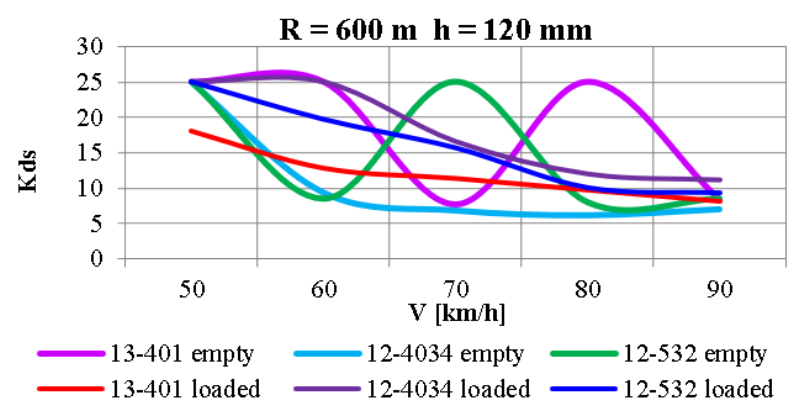

(b)

Figure 12. Variation of the safety factors of the wheel against derailment with the motion speed: (a) $R=350 \mathrm{~m}$ curve; (b) $R=600 \mathrm{~m}$ curve

The permissible value of the coefficient of vertical dynamics of the track $K_{\mathrm{vdt}}$ is calculated in accordance with the allowable dynamic load per unit of the railway track length from the group of the bogie axles $168 \mathrm{kN} / \mathrm{m}$, for all types of the rolling stock under study it is $\left[\mathrm{K}_{\mathrm{vdt}}\right]=$ 0.45. The coefficient of vertical dynamics of the track (Fig. 13, a, b) does not exceed the permissible standard value in both curves with radii of $R=350 \mathrm{~m}$ and $600 \mathrm{~m}$.

In the $R=350 \mathrm{~m}$ curve, all three types of rolling stock have almost identical $K_{\mathrm{vdt}}$ both in the empty and in the loaded mode, but in the $R=600 \mathrm{~m}$ curve the open wagon and the flat wagon have the best coefficients of the vertical dynamics (Fig. 13, b), except for moving at a speed of $70 \mathrm{~km} / \mathrm{h}$ in loaded mode. As in the case of the vertical dynamics of rolling stock, wagon types with a lower mass and lower center of mass have the best coefficients of vertical dynamics of the track.

The coefficient of horizontal dynamics of the track $K_{\text {hdt }}$ (Fig. 14 a, b), which is considered as a safety criterion of the assembled rails and sleepers against creep (shear), does not exceed the permissible value in curves with radii $R=350 \mathrm{~m}$ and $600 \mathrm{~m}$. 


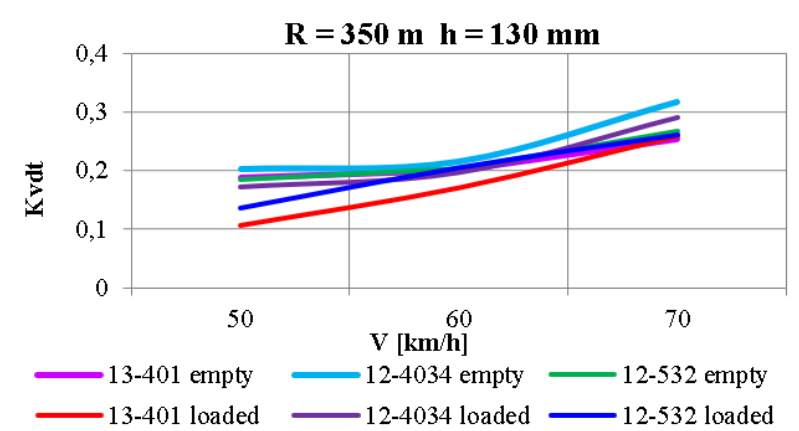

(a)

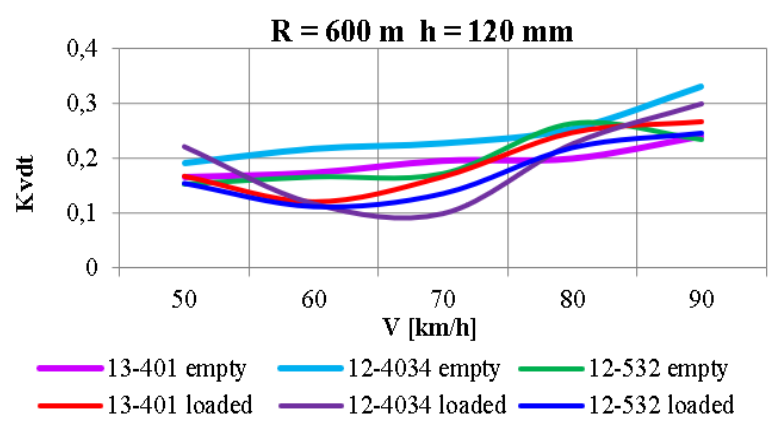

(b)

Figure 13. Variation of the coefficient of vertical dynamics of the track by the forces of the wheels and rails interaction with the motion speed: (a) $R=350$ m curve; (b) $R=600 \mathrm{~m}$ curve

An analysis of the results obtained for the coefficient of horizontal dynamics of the track $K_{\text {hdt }}$ shows that horizontal dynamics by the forces of the wheels and rails interaction is better for heavy wagons with a high center of mass.

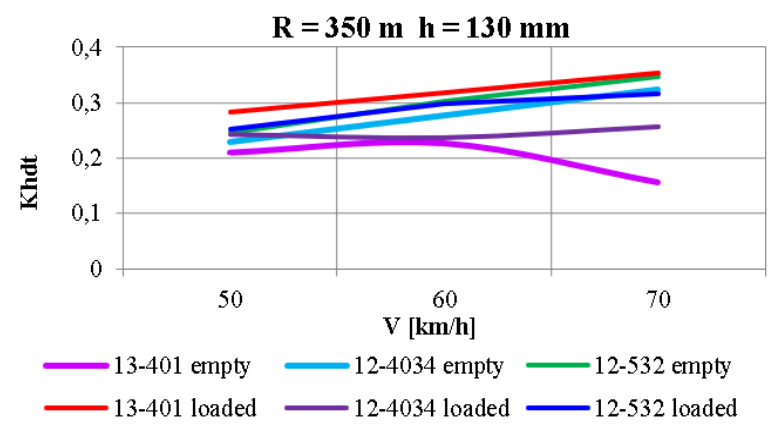

(a)

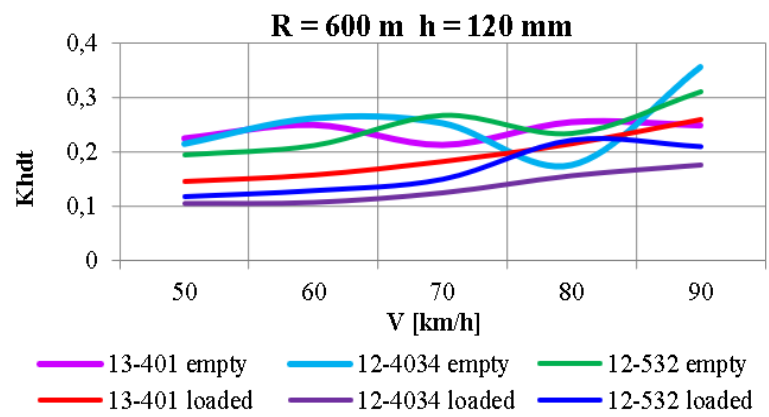

(b)

Figure 14. Variation of the coefficient of horizontal dynamics of the track by the forces of the wheels and rails interaction with the motion speed: (a) $R=350 \mathrm{~m}$ curve; (b) $\mathrm{R}=600 \mathrm{~m}$ curve

Fig. $15(a, b)$ shows the stability coefficient of the assembled rails and sleepers against creep (shear) $\varepsilon$.

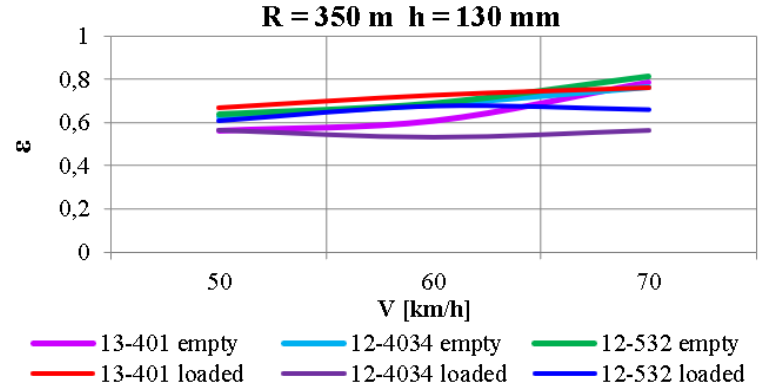

(a)

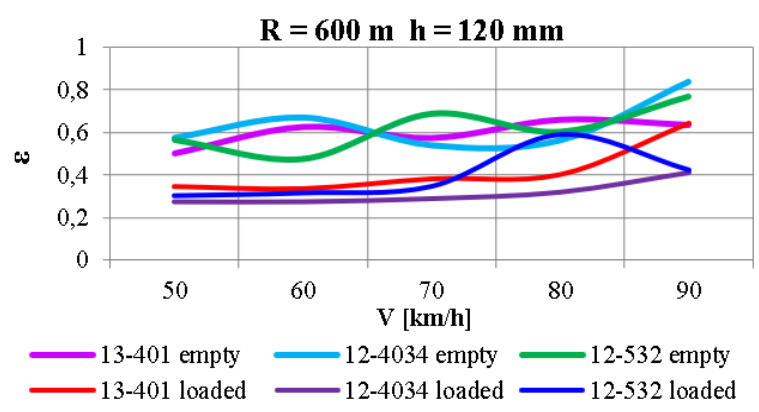

(b)

Figure 15. Variation of the stability coefficient of the assembled rails and sleepers from the transverse forces action with the motion speed: (a) $R=350$ m curve; (b) $R=600$ m curve

The admissible value of the stability coefficient of the assembled rails and sleepers from the action of transverse forces is $[\varepsilon]=0.85$. According to the calcu-lation results, the value of the stability coefficient of the assembled rails and sleepers from the action of trans-verse forces had less value than the permissible one in the track with crushed stone ballast. However, in the m curve at a speed of $90 \mathrm{~km} / \mathrm{h}$ an empty hopper wagon will have an effect on the assembled rails and sleepers close to the value allowed by the normative documentation.

The stability coefficient of the assembled rails and sleepers against creep (shear) $\varepsilon$ in the empty mode is much more influenced by the rail vehicle weight than the position of its center of mass. When loaded, the flat wagon with the long wheelbase has the worst factor values.

Lateral forces acting from the track to the wheel (horizontal forces) $Y_{l}$ (Fig. 16, a, b) to ensure stability against the wheel flanges creeping on the rails do not exceed the permissible value $\left[Y_{l}\right]=90 \mathrm{kN}$. In the empty mode, the lateral forces $Y_{l}$ have high values for the hopper wagon in both curves. In the loaded mode, all the studied types of rolling stock have almost the same values of horizontal forces acting from the track to the wheel, with the exception of moving of an open wagon at a speed of $80 \mathrm{~km} / \mathrm{h}$ along the $R=600 \mathrm{~m}$ curve.

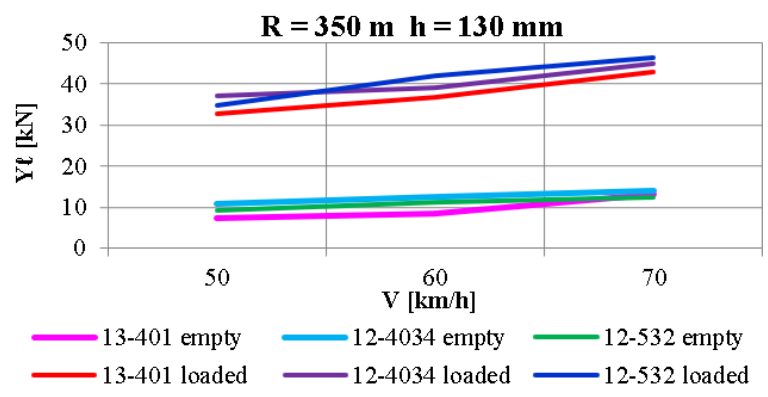

(a) 


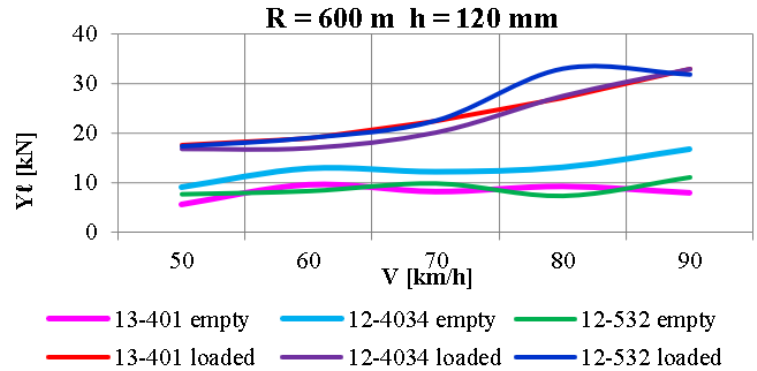

(b)

Figure 16. Variation of the lateral force acting from the track to the wheel with the motion speed: (a) $R=350 \mathrm{~m}$ curve; (b) $R=600$ m curve

As a criterion for permissible speeds setting, the maximum edge stresses occurring in the rail base are used. The edge stresses in the rail base $\sigma_{\mathrm{r}}$ should not exceed $200 \mathrm{MPa}$. According to the calculation results, edge stresses (Fig. 17, a, b) increase with increasing motion speed and do not exceed the permissible values for both loading modes in curves with a radius of $R=350$ $\mathrm{m}$ and $600 \mathrm{~m}$. The highest edge stresses arise when moving the hopper wagon in an empty or loaded mode.

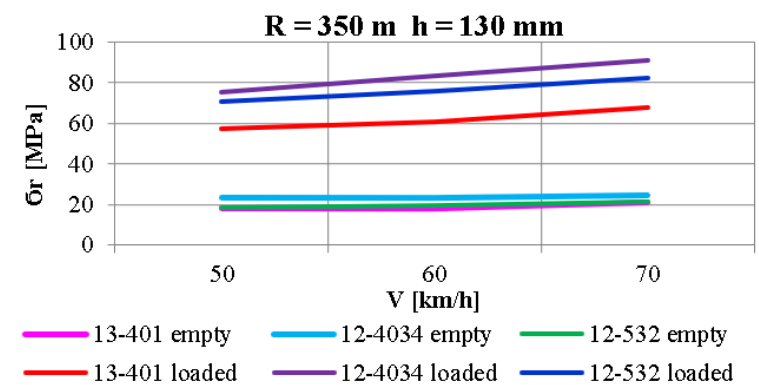

(a)

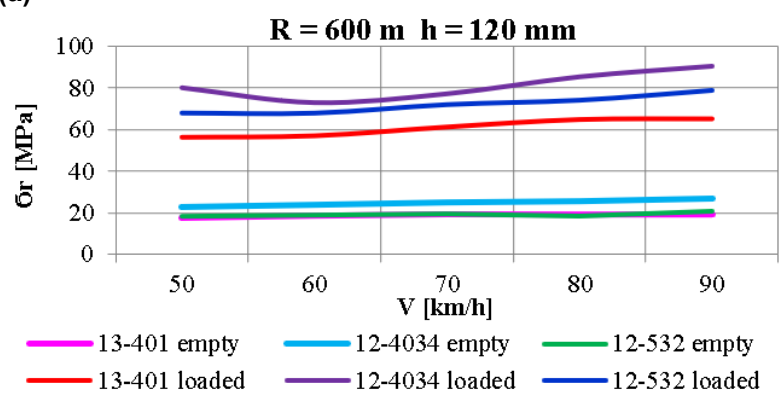

(b)

Figure 17. Variation of the edge stress in the rail base with the motion speed: (a) $R=350 \mathrm{~m}$ curve; (b) $\mathrm{R}=600 \mathrm{~m}$ curve

However, the results do not exceed the permissible values for both types of rails - before passage and after passage of the normative tonnage for a track with nonheat-treated rails $\mathrm{R} 65$.

The wear factor $F_{\mathrm{w}}$ (Fig. 18, a, b) is a relative characteristic value that reflects the physical phenomena that occur when skidding of the wheel flange along the rail side face.

This indicator is convenient for comparing rolling stock when assessing the wear rate of wheels and rails in the case of movement in curves of different radii. The wear of the flange and rails affects the safety of movement in the curve, since the wheel and rail contours change. In addition, the strong grinding of the wheel flange on the rail side face increases the resistance to the train movement.

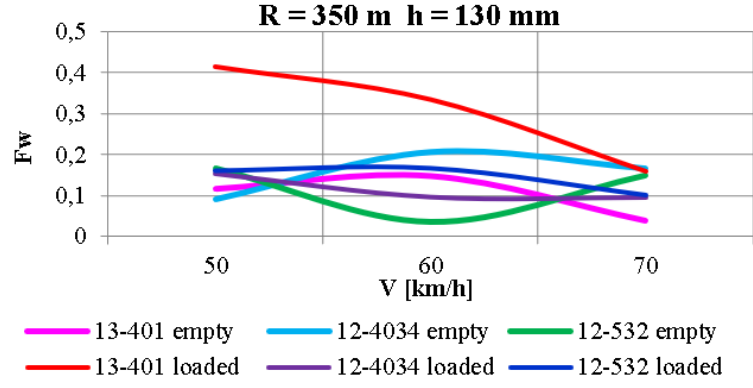

(a)

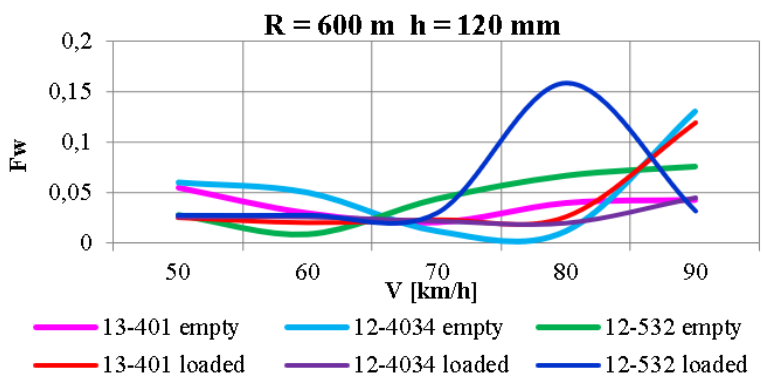

(b)

Figure 18. Variation of the wear factor of the side edge of the wheel tread with the motion speed: (a) $R=350 \mathrm{~m}$ curve; (b) $\mathrm{R}=600 \mathrm{~m}$ curve

In the $R=350 \mathrm{~m}$ curve, the wear factor of the wheel thread side face increases significantly when moving the loaded flat wagon at a speed of $50-60 \mathrm{~km} / \mathrm{h}$. At a speed of $80 \mathrm{~km} / \mathrm{h}$, the wear factor of the side edge of the wheel tread $F_{\mathrm{w}}$ increases significantly when moving the open wagon along the $R=600 \mathrm{~m}$ curve. In turn, there is a significant increase of $F_{\mathrm{w}}$ when moving the empty hopper wagon and the loaded flat wagon at a speed of $90 \mathrm{~km} / \mathrm{h}$ along the $R=600 \mathrm{~m}$ curve.

The wear factor of the side edge of the wheel tread $F_{\text {w }}$ is defined as a parameter equal to the product of the guiding force $Y_{\mathrm{d}}$ by the angle of attack (hunting) $\psi_{\mathrm{ws}}$ of the wheel against the rail. Consider the contribution of each of these parameters to the value of the wear factor. Fig. $19(\mathrm{a}, \mathrm{b})$ shows the effect of a speed on the guiding forces acting from the track to the wheel in the $R=350 \mathrm{~m}$ and $R=600 \mathrm{~m}$ curves.

The guiding forces acting from the track to the wheel $Y_{\mathrm{d}}$ increase significantly with increasing motion speed in the $R=350 \mathrm{~m}$ curve and have, on average, the same values for all types of rolling stock. The values of $Y_{\mathrm{d}}$ vary significantly for all types of rolling stock under study when moving along the $R=600 \mathrm{~m}$ curve at speeds of $80-90 \mathrm{~km} / \mathrm{h}$. Dependencies in Fig. 19, b allow us to conclude that the rolling stock parameters have a significant effect on the magnitude of the guiding forces in the curves of the mean radius.

Fig. $20(\mathrm{a}, \mathrm{b})$ shows the wheelset hunting $\psi_{\mathrm{ws}}$. The calculation results show that the flat wagon has the highest hunting angle of the wheelset $\psi_{\mathrm{ws}}$ when moving along the $R=350 \mathrm{~m}$ and $R=600 \mathrm{~m}$ curves in the empty mode at speeds of $50-60 \mathrm{~km} / \mathrm{h}$. In the loaded mode, in the curves of short radius (Fig. 20, a), the distance between bogie centers affects the stability of the wheelset, since the open wagon and the hopper wagon have smaller and almost identical values of $\psi_{\mathrm{ws}}$ according to the simulation results. 


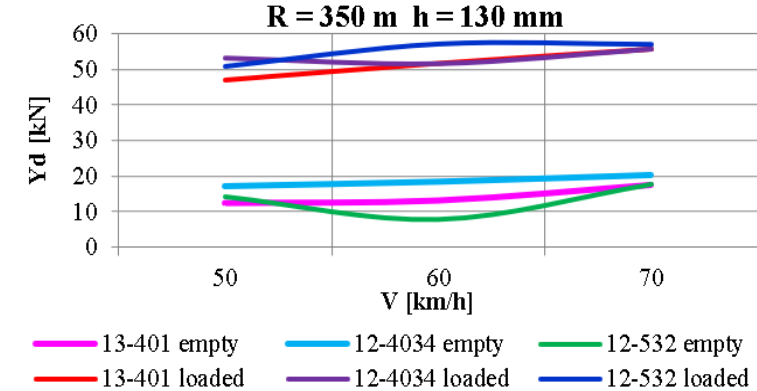

(a)

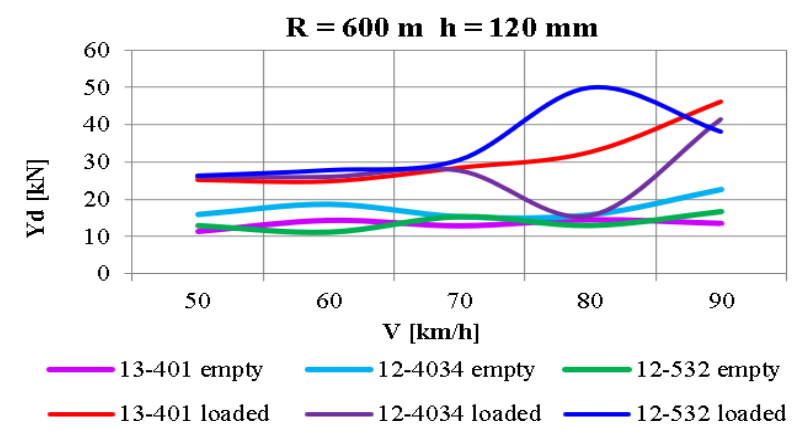

(b)

Figure 19. Variation of the guiding force acting from the track to the wheel with the motion speed: (a) $R=350 \mathrm{~m}$ curve; (b) $R=600 \mathrm{~m}$ curve

The hopper wagon has the lower values of the wheelset hunting when moving along the $R=600 \mathrm{~m}$ curve (Fig. 20, b) in the empty mode and the flat wagon has the largest values of $\psi_{\mathrm{ws}}$ at speeds of 50 and 90 $\mathrm{km} / \mathrm{h}$. The values of $\psi_{\mathrm{ws}}$ also increase for an empty open wagon when moving at a speed of $80 \mathrm{~km} / \mathrm{h}$ along curves of mean radius and they significantly differ from the other range of studied speeds.

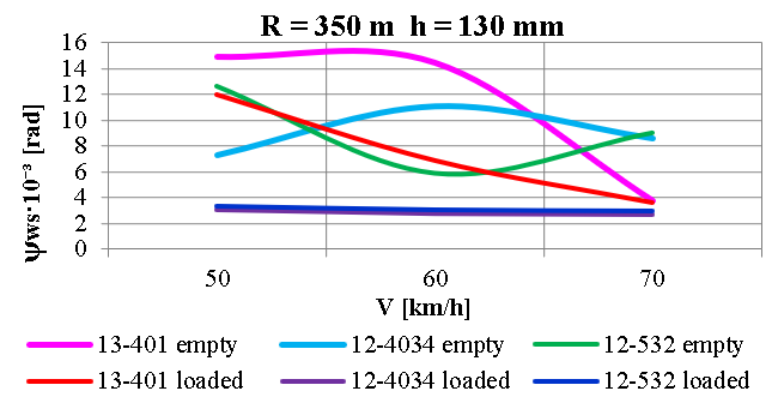

(a)

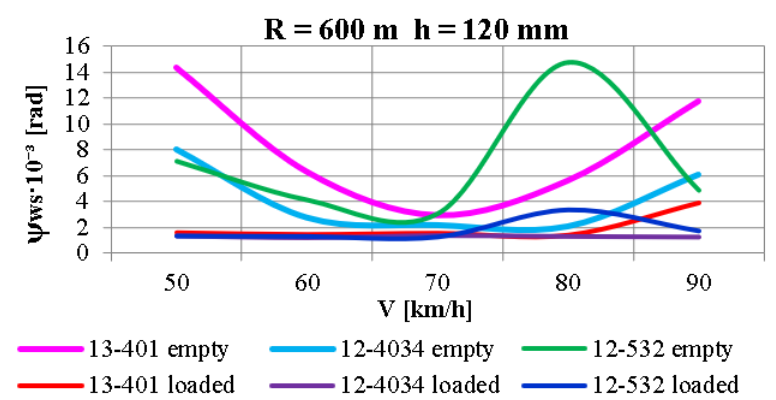

(b)

Figure 20. Variation of the wheelset hunting with the motion speed: (a) $R=350 \mathrm{~m}$ curve; (b) $R=600 \mathrm{~m}$ curve

The speed of $80 \mathrm{~km} / \mathrm{h}$ is considered critical for open wagons on bogies $18-100$ and is associated with a loss of motion stability when the dynamic transverse hunting oscillation of the wagon parts cease to decay, becoming stable (self-oscillations). The leading wheelset of the open wagon has the highest hunting values in both loading modes, with the exception of moving at a speed of $90 \mathrm{~km} / \mathrm{h}$ for a loaded flat wagon. The loaded hopper wagon has the smallest values of the hunting angle of the wheelset against the rail according to the simulation results. This makes it possible to put forward the assumption that the wheel sets of bogies 18-100 will have the smallest $\psi_{\mathrm{ws}}$ for wagons with increased weight and a distance between bogie centers as a hopper wagon for coal transportation 12-4034 has (Table 1).

\section{CONCLUSION}

The article presents an analysis of theoretical studies of the main dynamic indicators and indicators of the rolling stock and rails interaction on the example of 3 various types of freight wagons, the calculations were performed using the application software package. The practical significance of theoretical studies of the impact of various types of freight rolling stock under various loading conditions on the dynamic interaction with the track is as follows:

- The presented calculation results allow us to determine the optimal values of some wagon parameters when solving the problem of the operating wagon fleet modernization and determining the reserves for increasing their carrying capacity.

- The ability to solve the problem of finding optimal directions for the rail vehicle modernization.

- Contribution to the creation of technical conditions for new freight wagon building and operated wagons modernization.

- To increase the level of reliability and the transportation process safety in modern conditions in railway transport.

Based on the theoretical study, it is possible to draw the following conclusions:

- The calculation results have shown that the parameters of the studied wagon models have a more significant effect on the coefficients of the vertical dynamics of the central stage of suspension, horizontal dynamics and the safety factors of the wheel against derailment on the curves of the average radius.

- The values of such parameters as the tare of the wagon, the height of the center of mass and the length of the wagon base affect the angle of attack (wobble) of the wheelset, which leads to a change in the safety factors of the wheel against derailment.

- One of the reasons for the intensive wear of the wheels and rails of the studied wagon models is a change in running characteristics - an increase in the angle of attack of individual wheels due to the rotation of the bogie relative to the track or due to the rotation of the axle of the wheelset due to the displacement of the axle boxes in the openings of the side frames.

- The considered models of freight wagons as mechanical systems differ significantly from each other in their geometric, inertial and elastic dissipative characteristics. The study showed that to ensure a significant improvement in dynamic characteristics of 
specific wagon models, it is advisable to apply an individual approach to the selection of modernization elements of their running gears. Based on the studies performed, it is possible to conclude that the modernization of 18-100 model bogies for use in a specialized rolling stock will improve its dynamic characteristics.

Of course, the considered types and sizes of freight rolling stock is not enough for complete statistics, however, the theoretical modeling and the obtained calculation results demonstrate the feasibility of further research in this direction.

\section{REFERENCES}

[1] Kurhan, M.B., and Kurhan, D.M.: Providing the railway transit traffic Ukraine-European Union, Pollack Periodica, Vol. 14, No. 2, pp. 27-38, 2019. doi: 10.1556/606.2019.14.2.3

[2] Boronenko, Yu.P.: Cars with increased wheel loads on rails are a reserve for increasing the carrying and carrying capacity of railways, Transport of the Russian Federation. Journal of Science, Practice, Economics, No. 5(18), pp. 52-55, 2008. (in Russian).

[3] Muradian, L.A., Shaposhnyk, V.Yu., and Mischenko, A.A.: Methodological fundamentals of determination of unpowered rolling stock maintenance characteristics, Science and Transport Progress, Vol. 1, No. 61, pp. 169-179, 2016. doi: 10.15802/stp2016/61044 (in Russian).

[4] Muradian, L.A., Shaposhnyk, V.Yu., Podosenov, D.O.: Improving the reliability of freight wagons with the use of new manufacturing technologies and regeneration of working surfaces, Electromagnetic compatibility and safety in railway transport, No. 11, pp. 49-54, 2016. doi: 10.15802/ecsrt2016 /91337 (in Russian).

[5] Lee, W.G., Kim, J.-S., Sun, S.-J., and Lim, J.-Y.: The next generation material for lightweight railway car body structures: Magnesium alloys, in: Proceedings of the Institution of Mechanical Engineers, Part F: Journal of Rail and Rapid Transit, 1 January 2018, Vol. 232, Is. 1, pp. 25-42. doi: $10.1177 / 0954409716646140$

[6] Boronenko Y.P., and Filippova I.O.: Selection of constructive solutions of car elements with small empty weight, Science and Transport Progress, No 3(69), pp. 121-129, 2017. (in Russian).

[7] Ulianov, C., Önder, A., and Peng, Q.: Analysis and selection of materials for the design of lightweight railway vehicles, in: IOP Conference Series: Materials Science and Engineering 2nd Inter-national Conference on New Material and Chemical Industry, NMCI 2017, 18-20 November 2017, Sanya, China, Vol. 292, Is. 1, Paper 134405. doi: 10.1088/1757-899X/292/1/012072

[8] Shvets, A.O., Bolotov, O.O.: Influence of loading from the axle of a gondola car on its dynamic indicators and railway track, Science and Transport Progress, No. 1(79), pp. 151-166, 2019. doi: 10.15802/stp2019/158127
[9] Shimanovsky, A.O., Sakharau, P.A., Kuzniatsova, M.G.: Research of the modern absorbing apparatus power characteristics influence on the freight train inter-car forces, in: IOP Conference Series: Materials Science and Engineering, 2020, 985, Paper 012027. doi: 10.1088/1757-899X/985/1/01 2027

[10] Shvets, A.O.: Gondola cars dynamics from the action of longitudinal forces, Science and Transport Progress, No. 6(84), pp. 142-155, 2019. doi: $10.15802 /$ stp2019/195821

[11]Zhang, D., Tang, Y., Sun, Z., and Peng, Q.: Optimising the location of wagon gravity centre to improve the curving performance, Vehicle System Dynamics, pp. 1-15, 2020. doi: 10.1080/00423114.2020.1865546

[12] Shatunov, O. V., and Shvets, A. O.: Study of dynamic indicators of flat wagon with load centre shift, Science and Transport Progress, No. 2(80), pp. 127-143, 2019. doi: 10.15802/stp2019/165160

[13] Shatunov, O.V., Shvets, A.O., Kirilchuk, O.A., and Shvets, A.O.: Research of wheel-rail wear due to non-symmetrical loading of a flat car, Science and Transport Progress, No. 4(82), 102-117, 2019. doi: $10.15802 /$ stp2019/177457

[14]Zhang, D., Tang, Y., Peng, Q., and Ye Y.: Effect of mass distribution on curving performance for a loaded wagon, Nonlinear Dynamics, 2021. https://doi.org/10.1007/s11071-021-06386-3

[15] Stewart, M.F., Punwani, S.K. (John), Andersen, D.R., Booth, G.F., Singh, S.P., and Prabhakaran A.: Simulation of longitudinal train dynamics: case studies using the train energy and dynamics simulator (TEDS), in: Joint Rail Conference San Jose, California, USA, March 23-26, 2015, Paper JRC2015-5760, 2015. doi: 10.1115/JRC2015-5760

[16]Bosso, N., Magelli, M., and Zampieri, N.: Validation of a new longitudinal train dynamics code for time domain simulations and modal analyses, Int. J. Transp. Dev. Integr., Vol. 5, No. 1, pp. 41-56, 2021. doi: 10.2495/TDI-V5-N1-41-56

[17] Sun S, and Li F.: Longitudinal impulse dynamics of heavy haul train, Zhongguo Tiedao Kexue/China Railway Science, No. 36(4), pp. 136-138, 2015.

[18]Zhou Y, Shi Zh, Hecht M.: Comparison of friction draft gear models for simulation in longitudinal train dynamics, Vehicle System Dynamics, 2021. doi: 10.1080/00423114.2021. 1901943

[19]Zhu, T., Yang, B., Yang, C., Xiao, S., Yang, G., and Yang, B.: The mechanism for the coupler and draft gear and its influence on safety during a train collision, Vehicle System Dynamics, Vol. 56, No. 9, pp. 1375-1393, 2018. doi: 10.1080/00423114 .2017 .1413198

[20] Shvets, A.O.: Stability of freight wagons under the action of compressing longitudinal forces, Science and Transport Progress, No. 1(85), pp. 119-137, 2020. doi: $10.15802 /$ stp2020/199485

[21] Shvets, A.O., Shatunov, O.V., Dovhaniuk, S.S., Muradian, L.A., Pularyia, A.L., and Kalashnik, 
V.O.: Coefficient of stability against lift by longitudinal forces of freight cars in trains, in: Proc. 15th International Scientific and Technical Conference "Problems of the railway transport mechanics" (PRTM 2020), 2020 May 27-29, Dnipro, Ukraine, Vol. 985, Paper 012025, 2020. doi: 0.1088/1757-899X/985/1/012025

[22] Shaposhnyk, V.Yu.: Automatic coupler body. Payment 9920.05.01.00.006 RR. in: Ukrtransakad, Dnepropetrovsk, pp. 1-18, 2014. (in Russian).

[23] Neduzha, L.O., and Shvets, A.O.: Theoretical and experimental research of strength properties of spine beam of freight cars, Science and Transport Progress, No. 1(73), pp. 131-147, 2018. doi: 10.15802/stp2018/123457. (in Ukranian).

[24] Shaposhnyk, V.Yu., Shykunov, O.A.: Improvement of the construction of the body end plate of the gondola car, in: The 6th International scientific and practical conference "The world of science and innovation”, 14-16 January 2021, Cognum Publishing House, London, United Kingdom, 2021, pp. 1181-1187. (in Ukranian).

[25] Ramesh, M., Jafrey, Daniel D., Ravichandran, M.: Investigation on mechanical properties and wear behaviour of titanium diboride reinforced composites, FME Transactions, No. 47, pp. 873879, 2019. doi: 10.5937/fmet1904873R

[26] Kurhan, M., Kurhan, D., Novik, R., Baydak, S., and Hmelevska, N.: Improvement of the railway track efficiency by minimizing the rail wear in curves, in: IOP Conference Series: Materials Science and Engineering, 15th International Scientific and Technical Conference "Problems of the railway transport mechanics" (PRTM 2020) 27-29 May 2020, Dnipro, Ukraine, Vol. 985, Paper 012001, 2020. doi: 10.1088/1757-899X/985/1/012001

[27] Myamlin, S., Neduzha, L., Ten, O., and Shvets, A.: Spatial vibration of cargo cars in computer modelling with the account of their inertia properties, in: Mechanika 2010: Proc. of $15^{\text {th }}$ Intern. Conf., pp. 325-328, 2010.
[28] Shvets, A.O.: Specifics of determining the moments of inertia a freight wagons bodies, Bulletin of Certification of Railway Transport, No. 5(51), pp. 20-34, 2018. (in Ukrainian).

[29] Danovich, V.D. Spatial cars oscillations in inertia track, Thesis of doctor of technical sciences, Dnipropetrovsk National University of Railway Transport named after Academician V. Lazaryan, Dnipropetrovsk, 1982. (in Russian).

[30] Danovich, V.D., Malysheva, A.A.: Mathematical model of spatial oscillations of the coupling of five cars moving along a rectilinear section of the track, Transport. Stress Loading and Durability of a Rolling Stock, pp. 62-69, 1998. (in Russian).

\section{ДИНАМИЧКИ ИНДИКАТОРИ КОЈИ УТИЧУ НА ПРОЈЕКТНО РЕШЕЊЕ ЗА МОДЕРНИЗАЦИЈУ ТЕРЕТНОГ ЖЕЛЕЗНИЧКОГ ВОЗНОГ ПАРКА}

\section{А.О. Швец}

Возни парк има директног утицаја на економске показатеље транспортне индустрије и националну економију у целини, што захтева унапређење контроле и квантификовање динамичког оптерећења возног парка у циљу одржавања безбедних и поузданих железничких веза. У процесу пројектовања и функционисања возног парка квантитативна процена динамичког оптерећења представља хитан научни и технички проблем. Дата je анализа теоријских изучавања динамичких карактеристика возног парка на примеру отворених, равних и вагона бункера. Истраживање утицаја начина оптерећивања на динамичко оптерећење вагона има за циљ решење проблема предвиђања динамике возног парка и показатеља интеракције са пругом. Резултати теоријских истраживања узимају у обзир брзину кретања на закривљеној прузи кратког и средњег радијуса. 